\title{
Toksisitas Kemoterapi Leukemia Limfoblastik Akut pada Fase Induksi dan Profilaksis Susunan Saraf Pusat dengan Metotreksat 1 gram
}

\author{
Ketut Ariawati*, Endang Windiastuti**, Djajadiman Gatot** \\ * Bagian IKA Fakultas Kedokteran Universitas Udayana / RS Sanglah Denpasar \\ ** Divisi Hematologi Departemen IKA FKUI / RS Dr. Ciptomangunkusumo, Jakarta
}

\begin{abstract}
Latar belakang. Toksisitas kemoterapi dipengaruhi oleh sifat antiproliferasi obat sitostatik dan akan merusak sel yang mempunyai aktivitas proliferasi yang tinggi. Oleh sebab itu pemberian kemoterapi dapat menimbulkan efek samping.

Tujuan. Mengetahui efek samping kemoterapi leukemia limfoblastik akut (LLA) pada fase induksi dan fase profilaksis susunan saraf pusat secara klinis maupun laboratorium

Metode. Penelitian retrospektif deskriptif terhadap semua pasien leukemia limfoblastik akut baru dalam periode Januari 2005 - Desember 2006 di Departemen Ilmu Kesehatan Anak FKUI-RSCM Jakarta

Hasil. Didapatkan 41 pasien yang memenuhi kriteria inklusi dari 126 kasus baru LLA, terdiri dari pasien risiko tinggi (12 orang), dan risiko biasa (29 orang). Median usia 5,5 tahun, median lama pengamatan 39 minggu. Remisi setelah fase induksi didapatkan $86,2 \%$ pada risiko biasa, $75 \%$ pada risiko tinggi. Pada fase induksi penurunan terendah terjadi setelah pemberian kemoterapi yang pertama dan kedua. Pada fase profilaksis penurunan kadar hemoglobin, leukosit, $A N C$, trombosit yang terendah terjadi bervariasi yaitu setelah pemberian metotreksat (MTX) $1 \mathrm{~g} / \mathrm{m}^{2}$ yang pertama, kedua, dan ketiga. Peningkatan kadar SGOT/ SGPT yang tertinggi yaitu 7 - 12 kali normal terjadi pada fase induksi minggu kedua, sedangkan pada fase profilaksis peningkatan tertinggi yaitu 8,5 - $10 \mathrm{kali}$ normal terjadi setelah pemberian (MTX) $1 \mathrm{~g} / \mathrm{m}^{2}$ yang pertama. Didapatkan 7 orang dengan neuropati perifer setelah pemberian vinkristin yang kedua.

Kesimpulan. Toksitas kemoterapi LLA pada fase induksi terjadi setelah pemberian kemoterapi yang pertama dan kedua, sedangkan pada fase profilaksis SSP dengan MTX $1 \mathrm{gram} / \mathrm{m}^{2}$ terjadi setelah pemberian pertama, kedua, dan ketiga. (Sari Pediatri 2007; 9(4):252-258).
\end{abstract}

Kata kunci: toksisitas, kemoterapi, leukemia limfoblastik akut

\footnotetext{
Alamat korespondensi

Dr. Endang Windiastuti, SpA(K)

** Divisi Hematologi Onkologi Departemen Ilmu Kesehatan Anak FKUI- RSCM Jl. Salemba no. 6, Jakarta 10430.

Telepon: 021-3907744, 31901170 Fax.021-3913982.
}

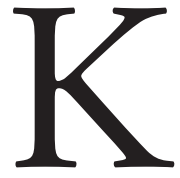

emoterapi bersifat kuratif bila dapat mengeradikasi semua sel-sel kanker sebelum obat tersebut menjadi resisten. pemberian kemoterapi dilakukan secara agresif dengan 
pemberian kombinasi beberapa macam obat kemoterapi, seperti halnya pengobatan fase induksi dan profilaksis (SSP) pada leukemia limfoblastik akut (LLA). ${ }^{1}$ Mekanisme kerja obat-obat kemoterapi tidak bersifat selektif, maka selain sel kanker yang terbasmi, sel normal yang bersifat aktif membelah seperti sel sumsum tulang, saluran pencernaan, folikel rambut, dan sistem reproduksi juga ikut terkena pengaruhnya. Beberapa efek samping yang tidak diinginkan akan timbul selama kemoterapi. ${ }^{2-5}$

Efek samping kemoterapi dapat terjadi akut dan jangka panjang. Efek samping akut dapat terjadi beberapa jam sampai beberapa minggu setelah pemberian kemoterapi, berupa mielosupresi, mual, muntah, alopesia, mukositis orointestinal, kelainan fungsi hati, alergi serta ulserasi lokal. Tingkat kerusakan organ akibat efek samping kemoterapi berbeda pada tiap individu tergantung berbagai faktor antara lain jenis dan dosis kemoterapi yang dipakai, jangka waktu pemberian, faktor individu seperti ras, status gizi, keadaan organ tempat detoksikasi, dan ekskresi obat tersebut. ${ }^{2,3,4}$

Penelitian dilakukan untuk mengetahui efek samping kemoterapi yang timbul baik klinis maupun laboratorium pada LLA fase induksi dan profilaksis SSP sehingga dapat dipantau dan diatasi sedini mungkin.

\section{Metode}

Penelitian dilakukan secara retrospektif deskriptif terhadap semua pasien LLA baru yang mendapatkan kemoterapi sesuai protokol LLA 2005 di Departemen Ilmu Kesehatan Anak FKUI-RSCM Jakarta antara Januari 2005 sampai dengan Desember 2006. Pasien dibagi menjadi 2 kelompok berdasarkan faktor risiko yaitu LLA risiko tinggi (RT) dan LLA risiko biasa (RB). Pasien LLA risiko tinggi apabila ditemukan salah satu kriteria, yaitu jumlah leukosit $>50.000 / \mu l$, dijumpai masa dimediastinum, didapatkan keterlibatan SSP, dan morfologi sumsum tulang L3 sesuai dengan kriteria FAB. Kriteria inklusi pada penelitian ini apabila pasien telah menyelesaikan kemoterapi fase induksi dan profilaksis SSP. Protokol kemoterapi LLA risiko biasa fase induksi dan fase profilaksis SSP tahun 2005 tertera pada Gambar 1. Protokol kemoterapi LLA risiko tinggi tidak mempergunakan deksametason window dan pemberian vinkristin ditambah 2 kali yaitu pada minggu kelima dan keenam.

Data penelitian diperoleh dari catatan medik yang meliputi identitas, gambaran klinis, pemeriksaan laboratorium dan keadaan terakhir pasien. Semua keluhan dan hasil laboratorium sebelum dan selama fase induksi serta fase profilaksis SSP dicatat, meliputi

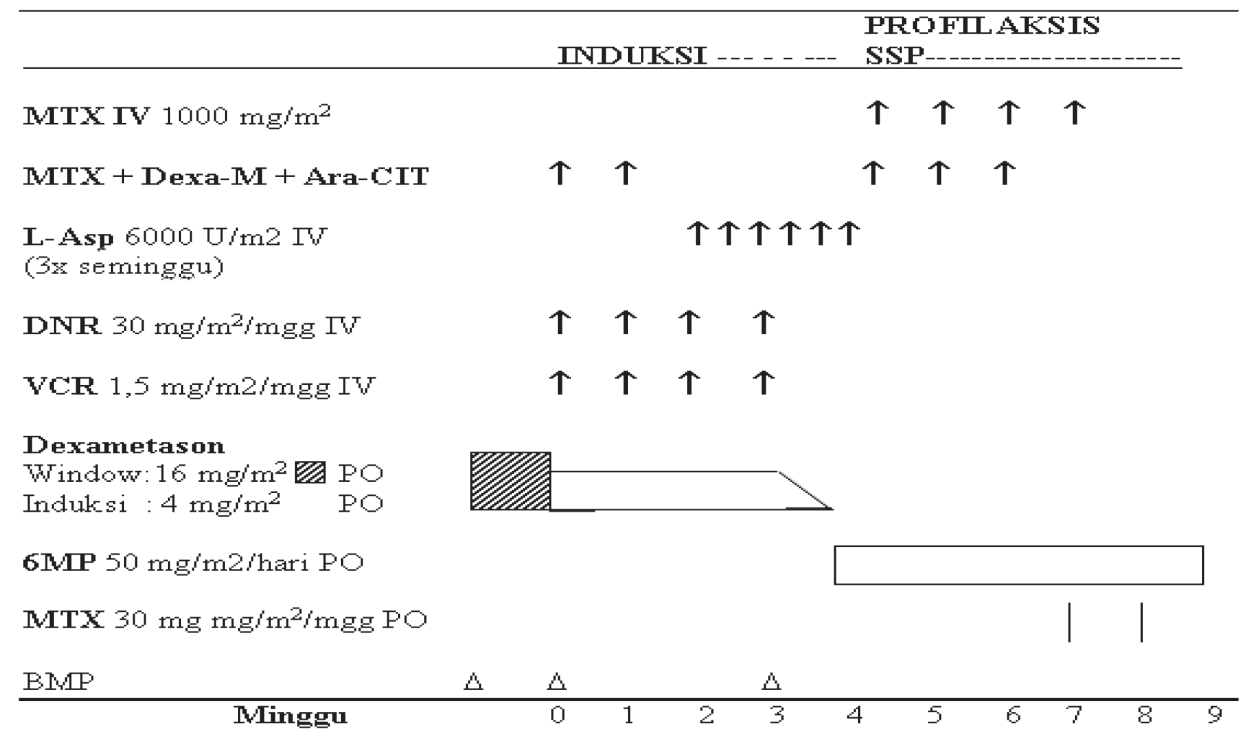

Gambar 1. Protokol kemoterapi LLA risiko biasa fase induksi dan fase profilaksis SSP 
Tabel 1. Karakteristik klinis dan laboratorium 41 pasien LLA

\begin{tabular}{|c|c|c|c|}
\hline Variabel & $\begin{array}{c}\text { Risiko } \\
\text { tinggi }\end{array}$ & $\begin{array}{c}\text { Risiko } \\
\text { biasa }\end{array}$ & Jumlah \\
\hline \multicolumn{4}{|c|}{ Umur saat diagnosis (tahun) } \\
\hline$<1$ & 0 & 0 & 0 \\
\hline $1-10$ & 9 & 26 & 35 \\
\hline$>10$ & 3 & 3 & 6 \\
\hline \multicolumn{4}{|l|}{ Jenis kelamin } \\
\hline Laki - laki & 8 & 12 & 20 \\
\hline Perempuan & 4 & 17 & 21 \\
\hline \multicolumn{4}{|l|}{ Status gizi } \\
\hline baik & 5 & 17 & 22 \\
\hline cukup & 5 & 9 & 14 \\
\hline buruk & 1 & 1 & 2 \\
\hline lebih & 1 & 2 & 3 \\
\hline \multicolumn{4}{|l|}{ Hepatomegali } \\
\hline $\mathrm{Ya}$ & 9 & 22 & 31 \\
\hline Tidak & 3 & 7 & 10 \\
\hline \multicolumn{4}{|l|}{ Splenomegali } \\
\hline $\mathrm{Ya}$ & 10 & 15 & 25 \\
\hline Tidak & 2 & 14 & 16 \\
\hline \multicolumn{4}{|l|}{ Limfadenopati } \\
\hline $\mathrm{Ya}$ & 10 & 12 & 22 \\
\hline Tidak & 2 & 17 & 19 \\
\hline \multicolumn{4}{|l|}{ Tumor mediastinum } \\
\hline $\mathrm{Ya}$ & 1 & 0 & 1 \\
\hline Tidak & 11 & 29 & 40 \\
\hline \multicolumn{4}{|l|}{ FAB } \\
\hline L1 & 8 & 28 & 36 \\
\hline L2 & 0 & 1 & 1 \\
\hline L3 & 4 & 0 & 4 \\
\hline \multicolumn{4}{|l|}{ Remisi fase induksi } \\
\hline $\mathrm{Ya}$ & 9 & 25 & 34 \\
\hline Tidak & 3 & 4 & 7 \\
\hline \multicolumn{4}{|l|}{ Outcome* } \\
\hline Remisi & 6 & 16 & 22 \\
\hline Relaps & 1 & 1 & 2 \\
\hline Lost to follow up & 1 & 8 & 9 \\
\hline Meninggal & 1 & 0 & 1 \\
\hline
\end{tabular}

*Akhir pengamatan

kadar hemoglobin, leukosit, $A N C$, trombosit (diperiksa setiap minggu), serta hasil kadar SGOT, SGPT, bilirubin total, kreatinin (diperiksa setiap 2 minggu). Data yang terkumpul dianalisis menggunakan program SPSS-13 kemudian disajikan dalam bentuk narasi, tabular serta grafik.

\section{Hasil}

Selama periode Januari 2005 sampai Desember 2006 didapatkan 126 kasus LLA baru. Delapan puluh lima kasus tidak disertakan ke dalam penelitian karena 26 orang mendapat kemoterapi MTX 500 mg, belum atau menolak kemoterapi 23 orang; meninggal sebelum kemoterapi 4 orang; pindah ke rumah sakit lain 4 orang; meninggal pada fase induksi 19 orang, lost to follow up 4 orang; data tidak akurat 5 orang, sehingga yang dilaporkan dalam penelitian 41 kasus LLA. Karakteristik klinis dan laboratorium subjek penelitian tertera pada Tabel 1. Usia saat diagnosis ditegakkan berkisar antara 2 tahun sampai 14 tahun dengan median 5,5 tahun. Lama pengamatan pasien antara 6 minggu sampai 355 minggu dengan median 39 minggu. Keadaan gizi buruk berdasarkan CDC NCHS-WHO 2000 ditemukan dalam jumlah sama pada kedua kelompok risiko yaitu 41 kasus, 2,4\% dari. Remisi setelah fase induksi didapatkan $86,2 \%$ pada risiko biasa dan $75 \%$ pada risiko tinggi.

Keluhan mual, muntah, stomatitis, diare, intake kurang, terbanyak terjadi pada minggu kelima yaitu setelah pemberian metotreksat (MTX) dosis 1 gram yang pertama (Gambar 2). Tujuh orang mengalami neuropati perifer yang dibuktikan dengan pemeriksaan elektromiografi (EMG) dengan gambaran neuropati axonal yang terjadi setelah pemberian VCR yang kedua sebanyak 6 orang dan 1 orang pada minggu keenam setelah pemberian MTX $1 \mathrm{~g}$ kedua. Keluhan tersebut bersifat sementara yang menghilang setelah minggu ketujuh. Enam orang lainnya mengalami rasa nyeri pada ekstremitas bawah dan 1 orang mengalami parastesi. Demam selama kemoterapi terdapat pada 21 pasien yang terdiri dari 22 kali episode demam pada fase induksi dan 15 kali episode demam pada profilaksis SSP. Pada fase induksi, kultur darah menunjukkan Acinetobacter calcoacolitis, Klebsiella pneumoniae, E. coli, Staphylococcus aureus dan jamur candida. Hasil kultur urin Acinetobacter calcoacolitis, Pseudomonas Sp, Klebsiella Sp, Proteus vulgaris, Staphylococcus viridan. Terdapat 4 episode demam dengan kultur yang steril. Pada fase profilaksis, hasil kultur darah menunjukkan kuman Pseudomonas sp, Acinetobacter calcoacolitis; hasil kultur urin Pseudomonas sp, Staphylococcus epidermidis. Dua orang pasien didiagnosis otitis media sekretorik kronis (OMSK) pada fase induksi setelah 


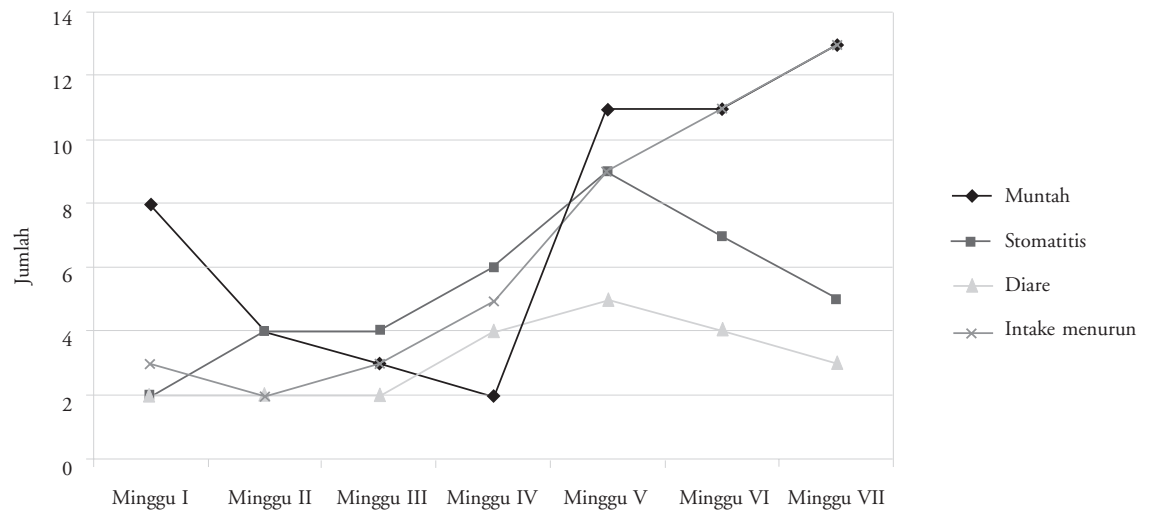

Gambar 2. Keluhan yang timbul selama pemberian kemoterapi

pemberian kemoterapi yang pertama dengan hasil kultur sekret telinga Staphylococcus epidermidis dan $A N C$ yang sangat rendah.

Hasil pemeriksaan laboratorium (Tabel 2) memperlihatkan penurunan kadar rata-rata hemoglobin, leukosit, $A N C$, selama pemberian kemoterapi fase induksi dan fase profilaksis SSP, sedangkan jumlah ratarata trombosit mengalami peningkatan.

Uji fungsi hati dan ginjal selama kemoterapi memperlihatkan hasil rata-rata normal, tidak berbeda dengan nilai SGOT, bilirubin total, kreatinin sebelum kemoterapi, sedangkan kadar rata-rata SGPT selama kemoterapi dua kali kadar rata-rata SGPT sebelum kemoterapi 76,6 mu/ml (SD 39,8); rentang 17,75-
$178 \mathrm{mu} / \mathrm{ml}$.

Kadar SGOT/SGPT tertinggi pada fase induksi tampak setelah pemberian kemoterapi kedua dengan kadar 308/485 mU/ml (7-12 kali nilai normal); sedangkan pada fase profilaksis SSP kadar SGOT/SGPT tertinggi tampak pada minggu kelima setelah pemberian MTX $1 \mathrm{~g} / \mathrm{m}^{2}$ pertama, dengan kadar 340/436 mU/ml (8,5-10 kali nilai normal).

Gambar 3 memperlihatkan waktu (minggu) terjadinya peningkatan fungsi organ (SGOT, SGPT, bilirubin total, kreatinin darah) selama pemberian kemoterapi. Terlihat peningkatan tertinggi terjadi pada minggu kelima.

Tabel 2. Kadar hemoglobin, leukosit, jumlah absolut neutrofi, trombosit sebelum dan selama kemoterapi induksi serta profilaksis SSP

\begin{tabular}{ccc} 
Rerata & \multicolumn{2}{c}{ Kadar terendah } \\
(standar deviasi) & $\begin{array}{c}\text { Fase. induksi } \\
\text { (minggu })\end{array}$ & Fase profilaksis \\
& & $($ minggu $)$
\end{tabular}

Hemoglobin $(\mathrm{g} / \mathrm{dl})$

Sebelum kemoterapi

Selama kemoterapi

Leukosit $(/ \mu \mathrm{L})$

Sebelum kemoterapi

Selama kemoterapi

ANC $(/ \mu \mathrm{L})$

Sebelum kemoterapi

Selama kemoterapi

Trombosit $(/ \mu \mathrm{L})$

Sebelum kemoterapi

Setelah kemoterapi
$11,2(1,88)$

$10,4(0,68)$

3,6 (1)

$5(7)$

$13.224(33.280)$

$3.660 \quad(1.357)$

500 (1)

400 (6)

$1.819(2.752)$

1.766 (757)

$0(1 ; 2)$

$50(5 ; 6 ; 7)$

$94.578(120.921)$

$240.576(98.696)$
$10.000(1)$

$20.000(5)$ 


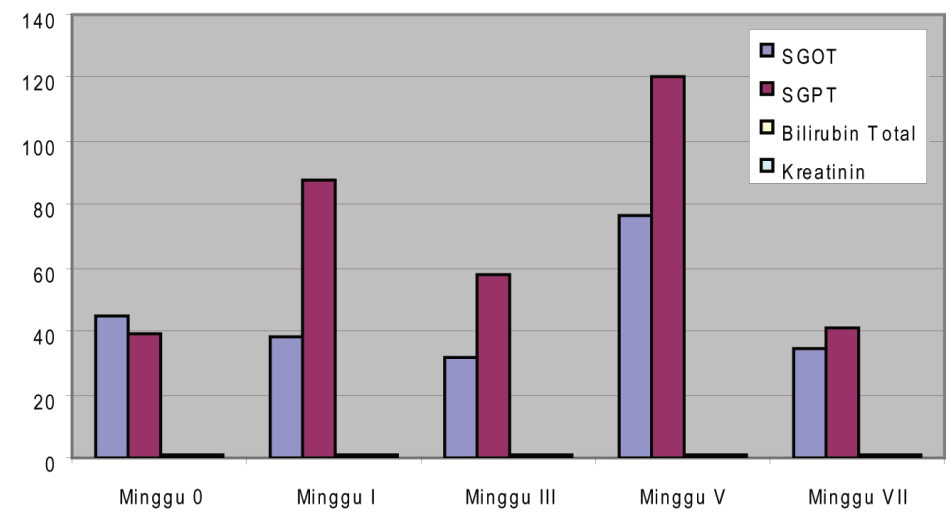

Gambar 3. Kadar rata-rata SGOT, SGPT, bilirubin total, kreatinin darah selama kemoterapi

\section{Diskusi}

Mekanisme kerja kemoterapi yang bersifat tidak selektif dan terapi kombinasi menyebabkan toksisitas obat meningkat. Toksisitas kemoterapi secara umum dapat dibagi dua yaitu bersifat akut dan jangka panjang. Toksisitas akut terjadi segera setelah pemberian kemoterapi (jam-minggu) dan bersifat sementara, sedangkan toksisitas jangka panjang bersifat permanen. ${ }^{2,6,7}$ Toksisitas akut antara lain depresi sumsum tulang, mual, muntah, alopesia, mukositis orointestinal, alergi, kelainan fungsi hati dan ginjal. Beberapa obat kemoterapi bersifat unik oleh karena toksisitas obat bersifat spesifik terhadap organ atau jaringan tertentu. ${ }^{2,6,7}$ Pada penelitian ini pemberian kemoterapi LLA pada fase induksi dan fase profilaksis SSP memperlihatkan berbagai toksisitas akut.

Keluhan mual, muntah setelah pemberian kemoterapi merupakan manifestasi toksisitas kemoterapi di organ gastrointestinal yang disebabkan oleh beberapa faktor. Pertama iritasi mukosa lambung dan duodenum yang merangsang pusat muntah di medula SSP melalui vas aferens nervus vagus. Faktor lain adalah aktivasi SSP akibat obstruksi, keterlambatan pengosongan lambung, reaksi inflamasi yang semua faktor tersebut disebabkan oleh kemoterapi. Beberapa obat kemoterapi dapat mengakibatkan efek mual dan muntah seperti MTX dengan dosis $>1 \mathrm{~g} / \mathrm{m}^{2}$ yang dapat menyebabkan gejala mual dan muntah pada $60 \%$ - 90\% pasien, sedangkan obat DNR, VCR hanya 30\% $-60 \% ., 5,9$ Pada penelitian ini didapatkan gejala mual dan muntah terbanyak terjadi setelah pemberian MTX dosis $1 \mathrm{~g} / \mathrm{m}^{2}$ kemudian setelah pemberian MTX intratekal; DNR dan VCR sesuai dengan teori yang ada.

Stomatitis merupakan proses inflamasi dan rasa nyeri dalam mulut setelah pemberian kemoterapi mengakibatkan perdarahan, ulserasi dan infeksi. Diare terjadi akibat kerusakan sel mukosa gastrointestinal yang disebabkan oleh kemoterapi. Umumnya stomatitis disebabkan oleh beberapa obat kemoterapi seperti MTX, DNR, dan bleomycin, sedangkan kemoterapi yang jarang menyebabkan stomatitis adalah 6-MP, VCR, vinblastin. Kemoterapi yang menyebabkan diare adalah MTX, hydroxyurea, dactinomycin. ${ }^{6,8,9}$ Pada penelitian ini juga didapatkan keluhan berupa stomatitis dan diare, banyak didapatkan setelah pemberian MTX dosis $1 \mathrm{~g} / \mathrm{m}^{2}$.

Neurotoksisitas perifer meliputi sensorik dan motorik disertai rasa nyeri hampir dijumpai pada semua penggunaan obat kemoterapi. Namun pada anak umumnya disebabkan oleh vinkristin. Kelumpuhan kaki dan tangan merupakan manifestasi berat neurotoksistas obat. Pada SSP gejala yang muncul adalah hoarseness dan diplopia. ${ }^{3,5,6,10}$ Aytac dkk ${ }^{11}$ mendapatkan gejala neuropati pada $82,5 \%$ dari 40 pasien LLA selama kemoterapi. Pemberian kemoterapi sistemik (VCR, MTX dosis tinggi) dan kemoterapi intratekal merupakan faktor predisposisi. Pada penelitian ini didapatkan 6 dari 41 orang mengalami neuropati setelah pemberian vinkristin dan 1 orang setelah pemberian MTX $1 \mathrm{~g} / \mathrm{m}^{2}$. Setelah dikonfirmasi dengan pemeriksaan EMG didapatkan neuropati axonal. 
Selama fase induksi terapi LLA, pasien akan mudah mengalami infeksi. Hal ini terjadi oleh karena pasien sering mengalami neutropenia dan penurunan daya tahan tubuh. Otitis eksterna nekrotikans atau otitis eksterna maligna merupakan infeksi berat pada kanal telinga dengan invasi ke dalam jaringan periaurikular. Pseudomonas sp merupakan mikroorganisme yang paling sering sebagai penyebab, namun dapat pula dijumpai Streptococcus faecalis, dan Streptococcus aureus. ${ }^{12}$ Pada penelitian ini dijumpai 2 orang dengan OMSK dengan hasil kultur Staphillococcus epidermidis.

Depresi sumsum tulang dapat disebabkan oleh toksisitas hampir setiap jenis kemoterapi, yaitu penurunan kadar hemoglobin, leukosit, ANC, serta trombosit. Penurunan kadar hemoglobin akibat kemoterapi bersifat sementara. ${ }^{8}$ Pada penelitian ini penurunan kadar hemoglobin terendah terjadi setelah pemberian kemoterapi pertama (fase induksi) dan setelah pemberian MTX $1 \mathrm{~g}$ intravena ketiga (fase profilaksis). Penurunan kadar leukosit terutama granulosit (ANC) dengan jumlah ANC kurang atau sama dengan 1000 mempunyai risiko untuk terjadinya infeksi. ${ }^{8}$ Pada penelitian ini didapatkan kadar ANC terendah setelah pemberian kemoterapi pertama dan kedua fase induksi, sedangkan pada fase profilaksis SSP terjadi setelah pemberian MTX $1 \mathrm{~g}$ kelima dan ketujuh. Depresi sumsum tulang dapat disebabkan oleh sel blast dalam sumsum tulang atau metastasis tumor padat ke sumsum tulang. Dalam keadaan ragu pemeriksaan sumsum tulang perlu dilakukan. Pada penelitian ini terjadi penurunan hemoglobin, leukosit, $A N C$, trombosit pada minggu pertama dan kedua fase induksi kemungkinan disebabkan oleh pendesakkan blast dalam sumsum tulang.

Toksisitas kemoterapi pada hati dapat disebabkan oleh pemberian MTX, cytosin arabinose, L-asparaginase, vinkristin. ${ }^{3,5,6,8}$ Pemantauan terhadap keadaan ini dapat dilakukan dengan pemeriksaan uji faal hati antara lain pemeriksaan kadar SGOT/SGPT dan bilirubin. Ahli hematologi lain mengemukakan bahwa kadang-kadang hasil pemeriksaan uji faal hati tidak seiring dengan derajat kerusakan jaringan hati. ${ }^{3}$ Pada penelitian ini didapatkan kadar tertinggi SGOT/SGPT terjadi setelah pemberian kemoterapi kedua (fase induksi) sedangkan pada fase profilaksis SSP peningkatan terjadi setelah pemberian MTX $1 \mathrm{~g} / \mathrm{m}^{2}$ pertama.

Metotreksat dosis tinggi $\left(\geq 0,5 \mathrm{~g} / \mathrm{m}^{2}\right)$ merupakan obat kemoterapi esensial yang dipergunakan dalam pengobatan LLA sejak tahun $1980,{ }^{13}$ yang bertujuan untuk mematikan sel kanker sebanyak mungkin sehingga menekan angka kejadian relaps. Di Norwegia dari tahun 1985-1991 dilaporkan pemberian kemoterapi MTX dosis tinggi $\left(6-8 \mathrm{~g} / \mathrm{m}^{2}\right)$ dapat menekan kejadian relaps SSP, dengan angka survival mencapai $79 \%$ dalam 10 tahun. ${ }^{13}$ Toksisitas akut akibat pemberian MTX dosis tinggi berupa mukositis dan supresi sumsum tulang. Peningkatan serum transaminase sering terjadi pada hari - hari pertama setelah pemberian MTX, sedangkan peningkatan kadar bilirubin jarang terjadi. Dengan pemberian leukovorin, hidrasi yang cukup, pemantauan MTX dalam plasma maka toksisitas dapat diturunkan. ${ }^{13,14}$ Obat MTX dosis tinggi bersifat neurotoksik khususnya bila diberi bersama-sama dengan terapi radiasi. Pemberian secara intravena dan intratekal jarang menimbulkan neurotoksisitas yang serius. Dosis yang sangat tinggi dosis 10 kali MTX $33,6 / \mathrm{m}^{2}$ masih ditoleransi, tidak menimbulkan sekuele neurologis. ${ }^{13}$

\section{Kesimpulan}

Di dapatkan toksisitas MTX $1 \mathrm{~g} / \mathrm{m}^{2}$ terutama setelah pemberian dosis pertama berupa peningkatan SGOT, SGPT, bilirubin total, serum kreatinin darah, yang bersifat sementara. Untuk mengetahui terjadinya toksisitas, pemantauan kadar MTX dalam plasma perlu dilakukan. Namun oleh karena keterbatasan alat pemantauan kadar MTX dalam plasma tidak dapat dilakukan. Upaya lain yaitu dengan mempertahankan hidrasi dan pemberian leucovorin efek samping yang terjadi dapat ditekan.

\section{Daftar Pustaka}

1. Pui CH, Crist WM. Biology and treatment of acute lymphoblastic leukemia. J Pediatr 1994; 124:491-503.

2. Balis FM, Holcenberg JS, Blaney SM. General Principles of Chemotherapy. Dalam: Pizzo PA, Poplack DG, penyunting. Principles and practice of pediatric oncology. Edisi ke-4. Philadelphia: Lippincott Williams \& Wilkins; 2002. h. 237-308.

3. Maria A. Efek samping sitostatika dan penanggulangannya. Dalam: Wahidiyat I, Gatot D, Mangunatmadja I, penyunting. Perkembangan mutakhir penyakit hematologi onkologi anak. Naskah lengkap Pendidikan 
Berkala Ilmu Kesehatan Anak XXIV. FKUI; 1991 6-7 September; Jakarta: Bagian Ilmu Kesehatan Anak Fakultas Kedokteran Universitas Indonesia, 1991.

4. National Cancer Institute. Chemotherapy for childhood cancers (diakses 3 Juni 2007). Didapat dari http:// ctep.cancer.gov/reporting/ctc.html

5. Rosenthal PE. Complications of cancer and cancer Treatment (diakses 3 Juni 2007). Didapat dari http: // dental.case.edu/classnotes/year3/ocancer/dinonc/chapter9.pdf

6. Berg SL, Balis FM, Poplack DG. Cancer Chemotherapy. Dalam: Nathan DG, Orkin SH, penyunting. Hematology of infancy and childhood. Edisi ke-5. Philadelphia: Saunders; 1998. h. 1201-26.

7. Vassal G, Vershuur. The principles of cancer chemotherapy in children. Dalam: Voute PA, Barret A, Stevens MC, Caron HN, penyunting. Cancer in children clinical management. Edisi kelima. Oxford: University; 2005. h. 44-54.

8. American Cancer Society. Making treatment decisions (diakses 3 Juni 2007). Didapat dari http : //www.cancer/
docroot/content/ETO.

9. Fischer DS, Knobf MT, Durivage HJ, penyunting. The cancer chemotherapy handbook. Carlsbad: Mosby; 1993. h. 475-545.

10. Sutaryo. Prinsip Kemoterapi pada Kanker Anak. Dalam: Permono B, Sutaryo, Ugrasena, Windiastuti E, Abdulsalam M, penyunting. Buku ajar hematologionkologi anak. Edisi kedua. Jakarta: Badan Penerbit IDAI; 2006. h. 227-35.

11. Aytac S, Yetgin S, Tavil B. Acute and long-term neurologic complications in children with acute lymphoblastic leukemia. Turkish J Pediatr 2006; 48:1-7.

12. Wolff LJ. Necrotizing otitis externa during induction therapy for acute lymphoblastic leukemia. Pediatrics 1989; 84:882-5.

13. Moe PJ. High-dose methotrexate in childhood ALL. Pediatr Hematol Oncol 2000; 17:615-22.

14. Cole PD, Kamen BA. High-dose methotrexate is lethal to rats, why give it to children?. Pediatr Hematol Oncol 2000; 17:609-13. 